Federal Reserve Bank of Minneapolis

\title{
QuarterlyReview
}

Winter 1983

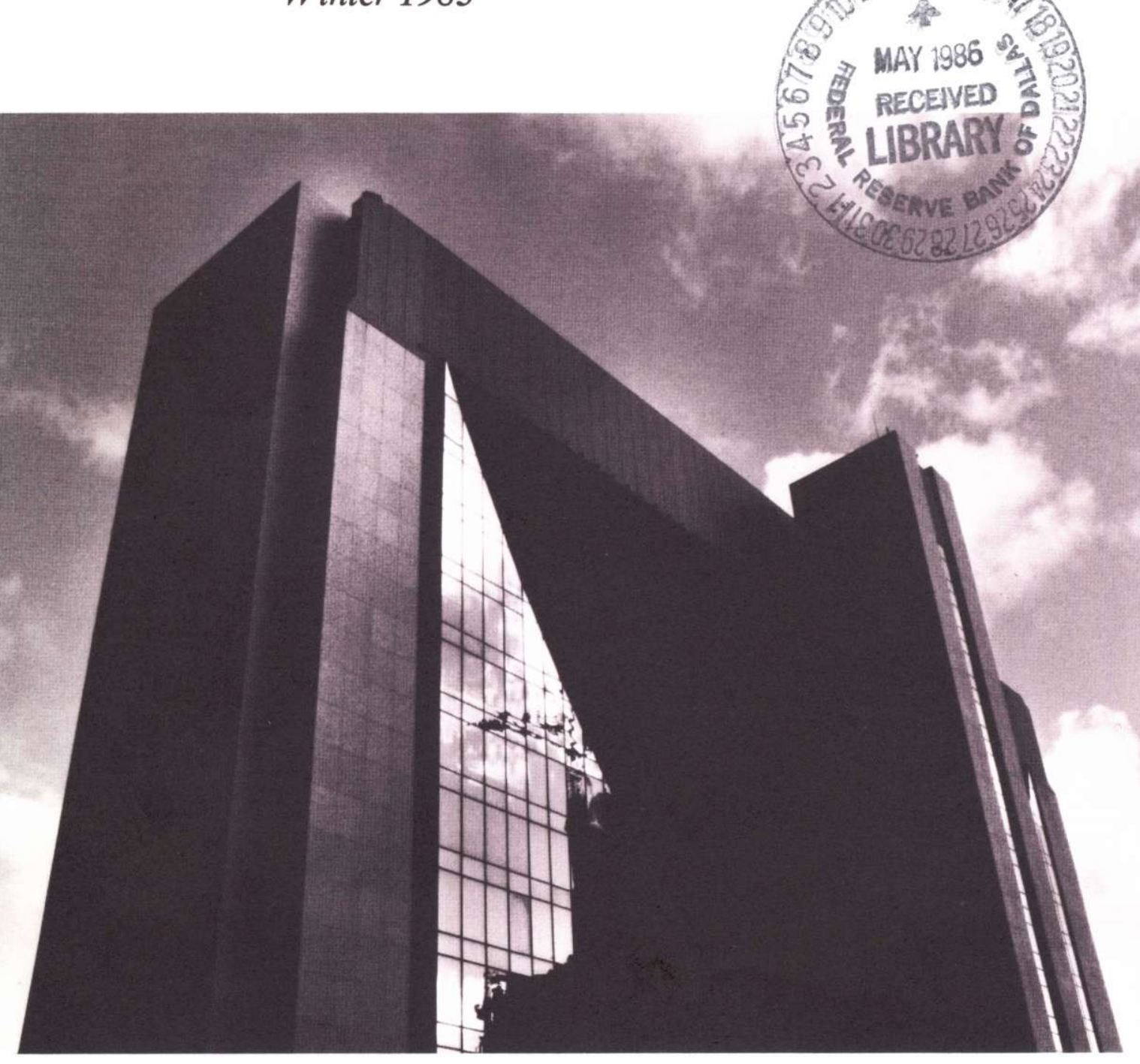

A Legal Restrictions Theory of the Demand for "Money" and the Role of Monetary Policy Neil Wallace (p. 1)

Higher Deficit Policies Lead to Higher Inflation Preston J. Miller (p. 8)

District Conditions

Recovery Likely to Be Stronger Than Expected

(p. 20) 
Federal Reserve Bank of Minneapolis Quarterly Review vol.7, No.1

This publication primarily presents economic research aimed at improving policymaking by the Federal Reserve System and other governmental authorities.

Produced in the Research Department. Edited by Richard M. Todd, Patricia Lewis, and Kathleen S. Rolfe. Graphic design by Phil Swenson and typesetting by Barbara Cahlander, Graphic Services Department.

Address requests for additional copies to the Research Department,

Federal Reserve Bank, Minneapolis, Minnesota 55480.

Articles may be reprinted if the source is credited and the Research

Department is provided with copies of reprints.

The views expressed herein are those of the authors and not necessarily those of the Federal Reserve Bank of Minneapolis or the Federal Reserve System. 


\section{A Legal Restrictions Theory of the Demand for "Money" and the Role of Monetary Policy*}

\section{Neil Wallace}

\section{Adviser}

Research Department

Federal Reserve Bank of Minneapolis

and Professor of Economics

University of Minnesota

In this paper, I discuss a simple theory that explains the coexistence of alternative assets, some of which have significantly higher yields or returns than others. ${ }^{1}$ The theory attributes such a paradoxical pattern of returns among assets to legal restrictions on private intermediation, an example being the widespread prohibition against private bank note issue. As I will show, this theory has as an almost immediate implication that monetary policycentral bank asset exchanges accomplished through open market operations or discount window lending-matters only in the presence of binding legal restrictions on private intermediation. ${ }^{2}$

In the first section, I describe obvious instances of paradoxical rate-of-return patterns and argue that these would disappear under laissez-faire-that is, in the absence of legal restrictions on private intermediation. The implication for monetary policy-that monetary policy under laissez-faire does not affect anything, not even the price level-is explained in the second section. In the third section, I discuss whether legal restrictions ought to be imposed. Although I do not arrive at a recommendation, I do discuss some of the considerations that are relevant to arriving at one.

\section{Legal Restrictions and the Coexistence of High- and Low-Return Assets}

An obvious instance of a paradoxical pattern of returns among assets is the coexistence of, on the one hand, U. S. Federal Reserve notes (U.S. currency) and, on the other hand, interest-bearing securities that are default-free. By default-free, I mean that these securities, with complete certainty, entitle their owner to a stated amount of currency at some future date. Examples of such securities are U.S. savings bonds and Treasury bills. Our first task is to identify the features of these securities that prevent them from playing the same role in transactions as Federal Reserve notes. For if they could play that role, then it is hard to see why anyone would hold non-interest-bearing currency instead of the interest-bearing securities.

U.S. savings bonds, although issued in various and small denominations, are nonnegotiable. U.S. Treasury bills are negotiable and, until recently, were bearer securities, but they have always been issued in large denominations, for the most part in $\$ 10,000$ denominations. I now argue that nonnegotiability in the case of savings bonds and large denomination in the case of bearer Treasury bills are necessary to explain why they cannot be substituted for Federal Reserve notes as alternative forms of currency.

*An earlier version of this paper was prepared for a November 1982 conference on interest rate deregulation and monetary policy sponsored by the Federal Reserve Bank of San Francisco.

1Hicks (1935) views this coexistence as the main puzzle facing monetary theory. He says (p. 5), “This, as I see it, is really the central issue in the pure theory of money. Either we have to give an explanation of the fact that people do hold money when rates of interest are positive, or we have to evade the difficulty somehow."

2See Fama 1980 and Hall 1982 for other discussions of the legal restrictions theory. Some other applications of the theory are listed in the box on page 3 . 
Consider what would happen if the Treasury started issuing bearer Treasury bills in small denominationsperhaps, $\$ 20$ s, $\$ 50$ s, and $\$ 100$ s. To be precise, suppose each such bill when issued says that the Treasury will pay the bearer at a date one year from the issue date or thereafter $x$ dollars of Federal Reserve notes, where $x$ is either 20,50 , or 100 . Let us say that these bills are distinguishable from Federal Reserve notes because they are red, not green, but that they are the same physical size as Federal Reserve notes (and do not smell too much worse or have other obnoxious but inessential characteristics). If such bills were to coexist with Federal Reserve notes, then would they sell at a discount (so that they bear interest) or would they sell at par (and not bear interest)?

If these bills and Federal Reserve notes were to coexist, then they would sell at par and be used interchangeably with Federal Reserve notes in the same way that Lincoln and Indianhead pennies coexisted and were used interchangeably. To see this, consider what would happen at a date very close to the maturity date of the bills. If the bills were selling at a discount at such a date, then everyone would prefer them to Federal Reserve notes because the bills would surely appreciate and the Federal Reserve notes would not. But if everyone chose the bills, then the Federal Reserve notes would not be held, and the two would not coexist. Therefore, at a date sufficiently close to the maturity date of the bills, the bills would sell at par if they and Federal Reserves notes were to coexist. Now consider a somewhat earlier date. Since this date bears the same relationship to the first date we considered as the latter did to the maturity date and since we have concluded that the bills would sell at par at the date near maturity, we can apply the argument used above to the earlier date. Our conclusion is the same: small-denomination bearer Treasury bills would sell at par if they and Federal Reserve notes were to coexist. Repeated application of this argument-considering dates further and further from the maturity date of the bills and nearer and nearer to their issue date-shows that these bills would sell at par at every date. ${ }^{3}$ Note, moreover, that if these small-denomination Treasury bills were selling at par, then there would be no incentive to turn them in at their maturity date; they would continue to circulate.

U.S. savings bonds differ from these hypothetical small-denomination Treasury bills only because they are very far from being bearer securities; they are nonnegotiable. Until very recently, when they ceased being bearer securities, U.S. Treasury bills differed only in their large denomination. That is why I claim that nonnegotiability in the case of savings bonds and large denomination in the case of bearer Treasury bills are necessary in order to explain how Federal Reserve notes can coexist with these securities while they bear substantial interest.

Our next task is to consider whether nonnegotiability and large denomination are sufficient for explaining the coexistence paradox. These features do explain why an individual with $\$ 10$ or $\$ 20$ in Federal Reserve notes does not switch them into savings bonds or Treasury bills even when those securities bear substantial interest. However, nonnegotiability and large denomination are not sufficient to explain the rate-of-return paradox because by themselves they fail to rule out arbitrage by financial institutions between such interest-bearing securities and small-denomination bearer notes. To see this, let us focus on denomination and begin with an analogy involving large and small packages of butter.

Suppose, for example, that we observe butter in onepound packages selling for $\$ 1$ per pound and butter in onehundred-pound packages selling for 25 cents per pound. Is it an adequate explanation of this spread in prices per pound to say that individual households buy one-pound packages because they may not have or want to devote $\$ 25$ to buying butter and they may not be able to transport or store one-hundred-pound packages? Obviously, such reasons are not adequate if there are sufficiently inexpensive ways to convert large packages into small packages and if there is free entry into the business of converting large packages into small packages.

If there is free entry into the business of converting large packages of butter into small packages, then the least costly technique for doing this sets an upper bound on the spread between prices per pound of large and small packages - that is, an upper bound on the quantity discount. Explanations of an observed quantity discount along the lines of individual households having small

${ }^{3}$ Liberty Bonds, which were issued during World War I as bearer securities in denominations as small as $\$ 50$, actually seem to have circulated as currency from time to time. In August 1918, the secretary of the treasury, William Gibbs McAdoo, complained that merchants were accepting Liberty Bonds in exchange for merchandise (New York Times, August 23, 1918).

On September 20, 1920, Theodore Hardee, the director of the Treasury Department's Government Savings Organization for the Twelfth District, sent a statement from the secretary of the treasury entitled "On the Evils of Exchanging Merchandise for Liberty Bonds" to the Commonwealth Club in San Francisco. The statement began: "It has been brought to my attention that numbers of merchants throughout the country are offering to take Liberty Loan Bonds at par, or even in some cases at a premium, in exchange for merchandise." 


\section{Some Applications of the Legal Restrictions Theory}

The legal restrictions theory described in this article has been applied to many issues in monetary theory and policy. A list and brief descriptions of some of these applications follow.

\section{International Monetary Systems}

Kareken and Wallace $(1978,1981)$ and Wallace (1979) apply the legal restrictions theory to exchange rate systems. In a system of freely floating exchange rates among fiat currencies issued by different countries, legal restrictions that inhibit substitution among the currencies are necessary in order for exchange rates to be determined. Absent such restrictions, no natural forces determine exchange rates.

\section{Multiple Government Liabilities}

Most governments impose legal restrictions on private intermediaries and issue a variety of liabilities-for example, currency and bonds. Bryant and Wallace (1983) rationalize both in terms of price discrimination. Legal restrictions create separate markets for the different liabilities by preventing arbitrage among them; the composition of government liabilities determines relative sales by the government in the separated markets. Bryant and Wallace display circumstances in which these devices permit the levying of a discriminatory inflation tax that is preferable to the levying of a uniform inflation tax.

\section{The Real Bills Doctrine}

This doctrine asserts that the quantity of money ought to vary with the needs of trade and that it will vary appropriately if private credit markets are allowed to function without interference. Sargent and Wallace (1982) offer a defense of this much-criticized doctrine.

\section{Commodity Money}

Sargent and Wallace (1983) model commodity money as one of several of the storable goods (capital goods) in a growth model. Among the topics addressed are the nature of the inefficiency of commodity money; the validity of quantitytheory predictions for commodity money systems; the circumstances under which one commodity emerges naturally as the commodity money; and the role of inside money (money backed by private debt) in commodity money systems. refrigerators are relevant only if barriers of one sort or another prevent the use of the least costly means or if individual household use of large packages is, in effect, the least costly way of carrying out such conversion. The latter seems unlikely.

Similar considerations apply in the case of the spread between the rate of return on Federal Reserve notes and that on default-free securities. In particular, consider a financial intermediary that does nothing but buy defaultfree securities-for example, U.S. Treasury bills-and issue bearer notes in small denominations with maturities that coincide with those of the default-free securities it holds. Such an intermediary is perfectly hedged so that, fraud aside, its bearer notes are as safe as the securities it holds as backing for them. It follows that such an activity gives rise to the same situation that prevails if the Treasury itself issues small-denomination bearer securities. If we suppose that, as part of its business, this intermediary takes actions that prevent fraud, then we conclude, exactly as we did for small-denomination bearer securities issued by the Treasury, that the bearer notes issued by such intermediaries would sell at par and be used interchange- ably with Federal Reserve notes if the two were to coexist.

Since the revenue for this intermediation business comes from buying default-free securities at a discount and issuing bearer notes at par, in an equilibrium with free entry the discount on default-free securities like Treasury bills must be small enough so that it is not profitable to expand this activity. That is the case when the discount is just sufficient to cover the costs of engaging in the business. In other words, in a laissez-faire system in which Federal Reserve notes and default-free securities like Treasury bills coexist, the yield or nominal rate of return on the latter is bounded above by the least costly way of operating such a financial intermediation business.

Rough estimates of the magnitude of this cost can be inferred from two sources: the cost of operating financial intermediaries in existing intermediary activities and the cost to the U.S. Treasury and Federal Reserve of issuing and maintaining the stock of Federal Reserve notes. Many financial intermediaries-common stock and money market mutual funds - operate at spreads of 1 percent or less. There is no reason to expect that the cost of intermediating securities like Treasury bills into bearer notes would be 
much different from the cost of operating these intermediaries. This view is buttressed by the fact that, for all but the smallest denominations, the cost to the Treasury and Federal Reserve of maintaining Federal Reserve currency is a small fraction of 1 percent of the outstanding stock. These observations suggest that our hypothetical intermediary could operate with a discount that is close to zero and, hence, suggest that the upper bound on nominal interest rates on safe securities under laissez-faire would be close to zero.

Thus far my argument says that if Federal Reserve notes and default-free securities like Treasury bills coexist under laissez-faire, then nominal interest rates are close to zero. But they may not coexist. Laissez-faire means, among other things, no reserve requirements, no capital controls of the sort recently put into effect in Mexico, and so on. In other words, laissez-faire means the absence of legal restrictions that tend, among other things, to enhance the demand for a government's currency. Thus, the imposition of laissez-faire would almost certainly reduce the demand for government currency. It could even reduce it to zero. A zero demand for a government's currency should be interpreted as the abandonment of one monetary unit in favor of another-for example, the abandonment of the dollar in favor of one ounce of gold. Thus, my prediction of the effects of imposing laissez-faire takes the form of an either/or statement: either nominal interest rates go to zero or existing government currency becomes worthless.

While these possibilities seem extreme, they are not unfamiliar to economists. They match almost completely two possibilities described by Samuelson (1947, p. 123):

It is true that in a world involving no transaction friction and no uncertainty, there would be no reason for a spread between the yield on any two assets, and hence there would be no difference in the yield on money and on securities. Hicks concludes, therefore, that securities will not bear interest but will accommodate themselves to the yield on money. It is equally possible and more illuminating to suppose that under these conditions money adjusts itself to the yield of securities. In fact, in such a world securities themselves would circulate as money and be acceptable in transactions; demand bank deposits would bear interest, just as they often did in this country in the period of the twenties. And if money could not make the adjustment, as in the case of metal counters which Aristotle tells us are barren, it would pass out of use, wither away and die, become a free good.

What is added in my discussion is the claim that the only significant frictions are those created by legal restrictions. Moreover, uncertainty seems not to be relevant because the hypothetical note-issuing intermediary described above is perfectly hedged. ${ }^{4}$

\section{Legal Restrictions and Monetary Policy}

In this section, let us make an additional assumption, which has already been hinted at above-namely, that a common and constant average-cost technology for the production and distribution of small-denomination bearer notes is available to the government and to potential private sector intermediaries. In terms of our butter analogy, this says that the government has neither a technological advantage nor a technological disadvantage relative to the private sector when it comes to converting large packages into small packages and that the cost per unit of producing small packages from large ones does not depend on the number produced. Under this assumption, my argument is that central bank intermediation activities, apart from outright credit subsidies, have no significant effects under laissez-faire.

In order to be concrete, I will discuss central bank intermediation in terms of an open market purchase of Treasury bills. This results in the private sector holding fewer bills and more Federal Reserve notes. Under laissezfaire, the equilibrium adjustment is a contraction in the scale of operations of private note-issuing intermediaries, a contraction that exactly offsets the open market purchase. If it is costly in terms of resources to carry out this private intermediation, then the contraction frees some resources-paper, people to run the presses, and so on. With technological symmetry between the private sector and the government, these are precisely the resources the government needs in order to provide and maintain the larger outstanding stock of government currency. In other words, under laissez-faire and technological symmetry,

\footnotetext{
${ }^{4}$ Some readers may wonder whether the coexistence in the U.S. of noninterest-bearing checking accounts and interest-bearing Treasury bills is an important counterexample to the claim that rate-of-return disparities are to be explained by legal restrictions. It is not, because government regulations and subsidies-interest ceilings, reserve requirements, zero marginal-cost check clearing by the Federal Reserve, and the failure to tax income in the form of transaction services-explain the way checking account services have been priced. In the absence of these forms of government interference, most observers predict that checking accounts would pay interest at the market rate with charges levied on a per transaction basis. (Note that under such pricing of demand deposit services, there would be no reason to distinguish the part of wealth that is subject to transfer by check from the part that is not, and checking accounts, whether distinguishable or not, could not be treated as part of the "cash" of inventory models of money demand. See, for example, Baumol 1952 and Tobin 1956.)
} 
the open market purchase does no more than change the location from the private sector to the government of a given quantity of an economic activity, the production of small-denomination bearer notes. Nothing else is affected, neither interest rates nor the price level nor the level of economic activity. A similar argument applies to open market sales. ${ }^{5}$

Matters are very different under binding legal restrictions on private intermediation. Let us discuss what would happen in terms of our butter analogy. Suppose the government has a legal monopoly on the business of converting large packages into small ones. Then much depends on the scale at which it chooses to operate. Under our assumptions, if the government chooses the output level that would have been produced in the absence of the legal monopoly, then the legal restriction does not matter. If it chooses a lower level of output, then it makes the legal restriction binding. An obvious measure of bindingness is the observed spread in prices per pound of small and large packages. How much greater is the observed spread than that which would obtain under laissez-faire?

The Federal Reserve does, of course, have a legal monopoly on the issue of small-denomination bearer notes in the United States. By its choice of an open market and discount window strategy, it determines how binding this legal restriction turns out to be. The appropriate measure of bindingness is the observed discount on Treasury bills. This corresponds exactly to the observed quantity discount on large packages of butter.

An important qualification is that the central bank not conduct its intermediation activities so as to incur losses. In terms of our butter analogy, if the government sells small packages at a price that does not permit it to cover costs, then even with free entry the government's operations clearly matter. To consider an intermediation example, suppose the central bank is allowed to incur losses and does so by granting both safe and risky loans at the laissez-faire interest rate on safe loans. Then, since risky loans would not otherwise be available at that rate, the central bank's lending has significant effects.

Thus, for a central bank constrained not to incur losses on average, our conclusion is that its intermediation matters if and only if there exist profitable arbitrage opportunities that the private sector cannot exploit because of legal restrictions.

The most objectionable of the assumptions used to obtain this result may be the constant-cost assumption. The provision of small-denomination bearer notes may be a decreasing average-cost activity, perhaps because the cost of inhibiting counterfeiting of the notes of a particular issuer does not increase in proportion to the value of the notes outstanding. If note issue is a decreasing cost activity, then the least costly way of providing smalldenomination bearer notes is by way of a single supplier. Moreover, if there are decreasing average costs, then we cannot conclude that an open market operation under laissez-faire simply shifts the location of a given activity between the government and the private sector. We can, however, continue to conclude that under laissez-faire the cost structure for providing small-denomination bearer notes implies an upper bound on nominal interest rates on default-free securities when these and non-interest-bearing currency coexist. Also, we can continue to conclude that the degree to which legal restrictions are binding is to be judged by the magnitude of such interest rates.

\section{Why Impose Legal Restrictions?}

So far, nothing has been said about what legal restrictions, if any, ought to be imposed and what central bank intermediation strategy ought to be followed. Although I will not arrive at a recommendation, I will discuss some of the presumed costs and benefits of legal restrictions on private intermediation.

Legal restrictions on private intermediation give rise to costs that are similar to those that accompany barriers to trade in other contexts: resources tend to be misallocated under binding restrictions. For example, consider a prohibition on private note issue. If this prohibition is binding, then some borrowers face higher interest rates on loans than they would if they, directly or through "banks," were able to borrow by issuing small-denomination bearer notes. The prohibition puts a barrier between borrowers and lenders and, hence, inhibits the carrying out of some beneficial intertemporal trade.

The same point can be made in a slightly different way. We are familiar with proposals that urge that the quantities of certain private sector liabilities be controlled-for example, proposals that urge that the quantity of private bank notes should be zero or that the quantity of deposits subject to check should grow at some prescribed rate. But

\footnotetext{
5 The result that central bank intermediation does not matter under laissezfaire also holds for central bank exchanges of Federal Reserve notes for other assets-risky mortgages, risky commercial loans, or common stock. It is a straightforward extension of a well-known finding in corporate finance called the Modigliani-Miller theorem. (See Stiglitz 1969 and Wallace 1981.)
} 
what is so special about deposits subject to check and private bank notes? They are particular private credit instruments. If it makes sense to control their quantities, why not those of other credit instruments? For example, most economists would not favor a proposal to constrain the dollar volume of mortgages on single family residences to grow at a prescribed rate. Almost certainly, most would say that it is a necessary feature of a well-functioning credit system that the number of mortgages be determined in the market and not be set administratively. But if this is right for one set of private credit instruments, why is it not right for all? No satisfactory answer has ever been given.

One presumed benefit of legal restrictions that has played a prominent role in prior discussions rests on the notion that it would be much more difficult to control the price level were it not for restrictions on credit instruments like private bank notes and checking deposits. Since some forms of private debt are better substitutes than others for government currency - or, under a gold standard, gold coins - this notion may be valid. In particular, if there is a variable demand for forms of credit that under laissez-faire would compete closely with government currency or gold coins, then it can happen that the price level would be more variable under laissez-faire than under legal restrictions that limit or prohibit the issue of such forms of private debt. ${ }^{6}$ Given that such restrictions, when they are binding, misallocate resources, it follows that there can be a tradeoff between achieving price level stability and achieving efficient resource allocation through credit markets.

However, this tradeoff presents a problem only if we accept price level stability as a goal, as an end in itself. That it should be a goal is not obvious. Although widely espoused as a goal, there exist no complete arguments leading to the conclusion that people are on average better off the more stable the price level, given the steps that have to be taken to attain greater stability of the price level. On the contrary, as Sargent and Wallace (1982) argue, the restrictions that make greater price level stability possible hurt some people and benefit others, while on average, in a certain sense, making all worse off.

I suspect that those who espouse price level stability as a goal do so partly because they think it is easy to attain; all that is needed is the right open market or intermediation strategy on the part of the central bank. That view, however, ignores what I argued above, namely, that central bank intermediation matters only in the presence of binding legal restrictions. Without such restrictions, it is no easier to achieve price level stability than it is to achieve stabili- ty of some relative price.

There is another potential benefit from legal restrictions on private intermediation that is less easy to dismiss. Such restrictions help governments tax asset holdings. Most legal restrictions on private intermediation have been and are the result of governments trying to enhance the demand for their liabilities. In general, such restrictions make it easier for governments to borrow and to tax by inflation. The fact that the restrictions misallocate resources is not decisive since the same can be said of virtually all taxes that are levied.

Finally, it should be noted that the above discussion does not deal with the transition from one set of restrictions to another. As with any major change in policy regime, substantial wealth redistribution may accompany alterations in legal restrictions on private intermediation.

\section{Concluding Remarks}

The theory I have described does two things. At a positive level, it suggests that we explain paradoxical rate-of-return patterns by way of legal restrictions on the kinds of assets and liabilities that the private sector can hold and issue. At a normative level, it suggests that we consider the consequences of alternative legal restrictions on the financial system in much the same way as we consider restrictions on trade in other contexts and, in particular, that we not be content with describing those consequences only in terms of their effects on variables like the price level and interest rates.
6For a complete example that exhibits this possibility, see Sargent and Wallace 1982 . 


\section{References}

Baumol, William J. 1952. The transactions demand for cash: An inventory theoretic approach. Quarterly Journal of Economics 66 (November): 545-56.

Bryant, John B., and Wallace, Neil. 1983. A price discrimination analysis of monetary policy. Research Department Staff Report 51. Federal Reserve Bank of Minneapolis.

Fama, Eugene. 1980. Banking in the theory of finance. Journal of Monetary Economics 6 (January): 39-57.

Hall, Robert E. 1982. Monetary trends in the United States and the United Kingdom: A review from the perspective of new developments in monetary economics. Journal of Economic Literature 20 (December): 1552-56.

Hicks, J. R. 1935. A suggestion for simplifying the theory of money. Economica, n. s. 2 (February): 1-19.

Kareken, John, and Wallace, Neil. 1978. International monetary reform: The feasible alternatives. Federal Reserve Bank of Minneapolis Quarterly Review 2(Summer): 2-7.

1981. On the indeterminancy of equilibrium exchange rates. Quarterly Journal of Economics 96 (May): 207-22.

Samuelson, Paul Anthony. 1947. Foundations of economic analysis. Cambridge: Harvard University Press.

Sargent, Thomas J., and Wallace, Neil. 1982. The real-bills doctrine versus the quantity theory: A reconsideration. Journal of Political Economy 90 (December): 1212-36.

1983. A model of commodity money. Research Department Staff Report 85. Federal Reserve Bank of Minneapolis.

Stiglitz, Joseph E. 1969. A re-examination of the Modigliani-Miller theorem. American Economic Review 59 (December): 784-93.

Tobin, James. 1956. The interest-elasticity of transactions demand for cash. Review of Economics and Statistics 38 (August): 241-47.

Wallace, Neil. 1979. Why markets in foreign exchange are different from other markets. Federal Reserve Bank of Minneapolis Quarterly Review 3 (Fall): 1-7.

1981. A Modigliani-Miller theorem for open-market operations. American Economic Review 71 (June): 267-74. 